\title{
Artikel
}

\section{Motieven voor naleving van de wettelijke anti-witwasmeldplicht}

\author{
J.T. Rakké MSc en prof. dr. mr. W. Huisman*
}

\section{Inleiding}

In de strijd tegen het witwassen hebben vijf Nederlandse banken aangekondigd om samen te werken, omdat banken op zichzelf enorm veel tijd en geld kwijt zijn aan de aanpak van witwassen. Daarnaast kan een klant die wordt afgewezen bij de ene bank wegens verdenkingen van witwassen relatief gemakkelijk een rekening openen bij een andere bank aangezien banken hun eigen separate cliëntonderzoeken en transactiemonitoring verrichten. De ambitie is om een organisatie op te richten die betalingstransacties gaat monitoren: Transactie Monitoring Nederland (hierna: TMNL). ${ }^{1} \mathrm{Zij}$ ziet voordelen in een vorm van gezamenlijke transactiemonitoring in de strijd tegen witwassen en terrorismefinanciering, omdat deze organisatie een efficiëntere samenwerking tussen banken zal bewerkstelligen. Een dergelijke centrale Transactie Monitoring Utility is ook onderdeel van het door de minister van Financiën en de minister van Justitie en Veiligheid gepresenteerde plan van aanpak voor de bestrijding van witwassen en onderliggende criminaliteit. $^{2}$ Zo'n Transactie Monitoring Utility moet de banken in staat stellen om informatie over transacties samen te brengen in een aparte organi-

* J.T. Rakké MSc is junior toezichthouder bij De Nederlandsche Bank. Prof. dr. mr. W. Huisman is hoogleraar criminologie aan de Vrije Universiteit Amsterdam. De eerste auteur heeft het artikel op persoonlijke titel geschreven, voortvloeiend uit haar scriptie voor de masteropleiding Criminologie aan de Vrije Universiteit Amsterdam.

1. Zie https://www.nvb.nl/nieuws/nederlandse-banken-bundelen-krach ten-tegen-witwassen.

2. Brief minister van Financiën van 30 juni 2019, nr. 2019-000010177 (plan van aanpak witwassen). satie die de uitvoering van de gezamenlijke monitoring verricht.

Dit initiatief is een reactie op de problemen die banken ondervinden bij het naleven van de wettelijke plichten inzake de bestrijding van witwassen. Vanwege ernstige tekortkomingen op dit terrein, waardoor honderden miljoenen euro's misdaadgeld konden worden witgewassen, heeft ING Bank een door het Openbaar Ministerie aangeboden transactie geaccepteerd waarmee de bank 775 miljoen euro boete heeft betaald en een compliancemonitor heeft aangesteld. ${ }^{3}$ Eerder werd de Rabobank beboet voor soortgelijke tekortkomingen, legde De Nederlandsche Bank (hierna: DNB) ter zake Triodos Bank een aanwijzing op en in 2019 werd bekend dat ook de ABN AMRO verdachte is in een strafrechtelijk onderzoek naar tekortkomingen in de naleving van de Wet ter voorkoming van witwassen en terrorisme financiering (hierna: Wwft).

Om witwassen te voorkomen is de $\mathrm{Wwft}$ in werking gesteld. De Wwft stelt financiële instellingen en andere meldingsplichtige instellingen in staat om cliëntenonderzoek te verrichten voordat een zakelijke relatie aan wordt gegaan en om transactiemonitoring uit te voeren gedurende de relatie. Indien ongebruikelijkheden worden opgemerkt, is de instelling verplicht om hiervan een melding te maken bij de Financial Intelligence Unit (hierna: FIU), zodat nader onderzoek kan worden verricht. Banken en andere meldingsplichtigen hebben daarmee de rol van 'poortwachter' gekregen van de integriteit van het financiële systeem in Nederland. Uit

3. Onderzoek Houston het strafrechtelijk onderzoek naar ING Bank N.V. Feitenrelaas en Beoordeling Openbaar Ministerie, Functioneel Parket en Landelijk Parket 2018. 
bovenstaande zaken blijkt dat naleving van de verplichtingen die $\mathrm{Wwft}$ aan deze taak stelt geen sinecure is.

Om meer inzicht te verkrijgen in de motivaties van financiële instellingen om een melding te maken, wordt in dit artikel de vraag beantwoord welke factoren een rol spelen bij meldingsplichtige instellingen om ongebruikelijke transacties te melden en hoe deze factoren motieven vormen voor het naleven van de $\mathrm{Wwft}$-meldplicht. Daartoe richt dit onderzoek zich op drie typen meldingsplichtige instellingen: banken, accountancykantoren en trustkantoren. Binnen deze drie sectoren zijn in totaal 25 interviews gehouden met verschillende functionarissen die betrokken zijn bij de naleving van de meldplicht: complianceofficers, CDD/AML-analisten en managers of partners. ${ }^{4}$ De interviews zijn volledig getranscribeerd en vervolgens thematisch en open gecodeerd met behulp van ATLAS.ti. ${ }^{5}$

In het navolgende wordt eerst de wettelijke meldplicht besproken en de wijze waarop ondernemingen in de drie sectoren geacht worden deze na te leven. Vervolgens worden drie soorten motieven voor het naleven van wettelijke regels door en binnen ondernemingen besproken. Daarna wordt onderzocht welke motieven en de door de respondenten genoemde factoren een rol spelen bij het melden van ongebruikelijke transacties en zodoende bijdragen aan de naleving van de wettelijke meldplicht. Ten slotte worden enkele conclusies getrokken over de motivaties van banken, accountancy- en trustkantoren om de wettelijke meldplicht na te leven.

\section{Wettelijke meldplicht}

In 1989 werd het internationale samenwerkingsverband Financial Action Task Force (hierna: FATF) opgericht met als doel het tegengaan van witwassen van crimineel vermogen. Later kwam daar het tegengaan van terrorismefinanciering bij. De FATF geeft aanbevelingen aan zijn lidstaten, die gelden als de internationale standaard van de aanpak van witwassen. ${ }^{6}$ In 1991 werd de eerste anti-witwasrichtlijn (91/308/EEG) van kracht. Deze richtlijn had als doel het voorkomen van het gebruik van het financiële stelsel voor het witwassen van geld. In Nederland werd deze richtlijn in 1993 geïmplementeerd via de Wet identificatie bij dienstverlening (hierna: WID) en de Wet melding ongebruikelijke transacties (hierna: Wet MOT). ${ }^{7}$ Ongebruikelijke transacties moesten gemeld worden aan het onaf-

4. 9 in de bankensector, 7 in de accountancysector, 9 in de trustsector. In totaal werden 157 potentiële respondenten per mail benaderd.

5. A. van Staa \& J. Evers, "“Thick analysis": strategie om de kwaliteit van kwalitatieve data-analyse te verhogen', KWALON. Tijdschrift voor Kwalitatief Onderzoek in Nederland 2010, 43(1), p. 5-12.

6. T. Doyle, 'Cleaning up anti-money laundering strategies: Current FATF tactics needlessly violate international law', Houston Journal of International Law, 24(2), 2001, p. 280-312.

7. Richtlijn 2005/60/EG van het Europees Parlement en de Raad van 26 oktober 2005 tot voorkoming van het gebruik van het financiële stelsel voor het witwassen van geld en de financiering van terrorisme. hankelijke Meldpunt Ongebruikelijke Transacties (hierna: MOT). Tegenwoordig is dat de FIU. Om de Nederlandse wetgeving in overeenstemming te brengen met de eerste drie richtlijnen en de FATF, werden in 2008 de Wet MOT en de WID samengevoegd en vervangen door de $\mathrm{Wwft}^{8}$ De Wwft reikt instellingen instrumenten aan voor het bestrijden van witwassen zoals het identificeren van cliënten, het verifiëren van identiteit, natrekken wie de uiteindelijke belanghebbende is (ultimate benificial omner (hierna: UBO)), en het melden van ongebruikelijke transacties. Voor de trustkantoren werd in 2014 een eigen wet ontwikkeld waarin ook wordt verwezen naar de verplichtingen van de $\mathrm{Wwft}$, namelijk de Regeling integere bedrijfsvoering Wtt 2014 (hierna: Rib Wtt 2014). De regeling is sinds 2018 vernieuwd onder de naam Wet toezicht trustkantoren 2018 (hierna: Wtt 2018).

Terwijl alweer de vijfde anti-witwasrichtlijn op 10 januari geimplementeerd is (AMLD5), ${ }^{9}$ is met de derde richtlijn een belangrijke wijziging geweest in de wijze waarop ook in Nederland ondernemingen aan de wettelijke meldplicht moeten voldoen. De eerste twee richtlijnen en de Nederlandse wettelijke vertaling daarvan volgden een zogenaamde rule-based benadering. Deze benadering gaat uit van het opleggen van specifieke regels die bedrijven duidelijk en nauwkeurig voorschrijven wat men moet doen en hoe men zich moet gedragen. Dergelijke regels verouderen echter snel en vergen grote inspanning van de overheid aangezien zij continue controle vergen. Om deze reden is vanaf de derde anti-witwasrichtlijn een verschuivingstendens ontstaan richting een risk-based benadering. ${ }^{10}$

Deze risk-based benadering houdt in dat de meldplichtige onderneming bij elke samenwerking de potentiële risico's van betrokkenheid bij witwashandelingen en/of het financieren van terrorisme moet inschatten en deze regelmatig moet controleren zolang de relatie standhoudt. Indien sprake is van een hoog risico zal een verscherpt cliëntenonderzoek verricht moeten worden. Meldplichtigen zijn daarbij relatief vrij in de toepassing van de regels omtrent cliëntenonderzoeken aangezien de wet alleen voorschrijft wat moet worden bereikt, maar niet op welke manier dit moet. Het idee is dat de ruimte voor eigen invulling en uitvoering zorgt voor een praktischer toepassing van de Wwft in de praktijk. ${ }^{11}$ De implementatie van de principle-based naleving van de

8. P.A.M. Verrest, 'De Wet ter voorkoming van witwassen en financieren van terrorisme', Ars Aequi 57(11), 2008, p. 823-830.

9. Richtlijn EU 2018/843 van het Europees Parlement en de Raad van 30 mei 2018 inzake de voorkoming van het gebruik van het financiële stelsel voor het witwassen van geld of terrorisme financiering, tot wijziging van Richtlijn (EU) 2015/849 inzake de voorkoming van het gebruik van het financiële stelsel voor het witwassen van geld of terrorismefinanciering, en tot wijziging van de Richtlijnen 2009/138/EG en 2013/36/EU.

10. A. Amicelle, 'Policing through misunderstanding: Insights from the configuration of financial policing', Crime, Law and Social Change, 69(2), 2018, p. 207-226.

11. W. Gohres, 'De nieuwe Wet ter voorkoming van witwassen en financieren van terrorisme', Spotlight 15(3) 2008, p. 23-27. 
meldplicht vereist meer en specifieke kennis en expertise, teneinde op valide en betrouwbare wijze risico-indicatoren die kunnen duiden op witwassen te kunnen vaststellen.

Binnen meldplichtige ondernemingen is de uitwerking van de toepassing van wettelijke regels de taak van de afdelingen compliance. Die toepassing dient te worden geborgd in het compliancemanagementsysteem. Het meest gangbare model om de naleving te bewerkstelligen, is dat van de zogenaamde three lines of defense. ${ }^{12}$ In dit model is de eerste lijn het lijnmanagement dat verantwoordelijk is voor risicomanagement en controle van de onder een leidinggevende vallende medewerkers en processen. De tweede verdedigingslijn wordt gevormd door de afdelingen risicomanagement en compliance die de eerste lijn daarin steunen en controleren. De derde lijn de internal audit-functie die onder andere de inrichting en werking van de eerste en tweede lijn controleert. De informatie over ongebruikelijke transacties die nodig is voor de naleving van de meldplicht kan uit de reguliere bedrijfsvoering in de eerste lijn komen. Bij de banken kan deze ook uit het customer due dilligence (hierna: $\mathrm{CDD}$ ) en know your customer (hierna: KYC)-onderzoek komen dat juist ook met dit doel onder de compliancefunctie wordt verricht. Omdat het vervullen van de poortwachtersrol een kerntaak van banken is geworden, zijn de CDD- en KYC-processen in de eerste lijn geplaatst. Het besluit te melden zal echter samen met de tweede lijn worden genomen.

\section{Motieven voor naleving}

In wetenschappelijk onderzoek naar naleving van weten regelgeving door ondernemingen worden drie soorten motivaties onderscheiden: economische, sociale en normatieve motieven. ${ }^{13}$ Economische motieven refereren aan het belang van de onderneming om economische doelen te bereiken, zoals het maximaliseren van winst, omzet of marktaandeel. Daarbij worden tegen het licht van deze doelen kosten en baten van compliance en noncompliance afgewogen.

Sociale motieven refereren aan het belang van de onderneming om waardering en respect te krijgen van voor de onderneming relevante actoren zoals klanten, werknemers, branchegenoten, omwonenden of het bredere publiek. Sociale motieven betreffen het voldoen aan descriptieve normen en prescriptieve normen. Descriptieve normen gaan over de perceptie wat relevante anderen - zoals collega's - doen in gelijkende situaties en prescriptieve sociale normen hebben betrekking wat

12. R. van Altena, 'Risk Management', in: S. Bleker-Van Eijk \& R.A.M. Houben (red.), Compliance \& Integrity Management. Theory and Practice, Alphen aan den Rijn: Wolters Kluwer 2018, p. 161

13. C. Parker \& V. Lehmann Nielsen, Explaining Compliance: Business Response to Regulation, Cheltenham, UK: Edward Elgar Publishers 2011. mensen denken dat van hen wordt verwacht. ${ }^{14}$ Wanneer ondernemingen zien dat anderen de wet naleven en men voelt dat dat ook van de eigen onderneming wordt verwacht, is dat een motief om dat ook te doen.

Waar sociale motieven gaan over wat ondernemingen denken over wat van hen wordt verwacht, gaan normatieve motieven over wat ondernemingen vinden dat van hen mag worden verwacht. Normatieve motieven refereren aan het belang van de onderneming om regels na te leven, vanuit het principe dat regels moeten worden nageleefd of vanwege het onderschrijven van het belang van een betreffende regel. Normatieve motieven worden sterk gevormd door de bedrijfscultuur en de tone at the top die uiteindelijk persoonlijke normen van medewerkers beïnvloeden. ${ }^{15}$ Persoonlijke normen worden daarmee ook beïnvloed door sociale normen: wat men vindt, wordt beinvloed door wat anderen doen of van hen verwachten. Morele opvattingen kunnen sterke drijfveren voor regelnaleving zijn. Indien de morele verplichting tot naleving niet gevoeld wordt, zal compliance gebaseerd worden op beoogde kosten en baten. ${ }^{16}$ Kortom, de morele opvattingen van personen over regels en het belang van de naleving ervan zijn van groot belang voor de meldingsbereidheid.

Er kunnen dus verschillen soorten motieven zijn om een wettelijk voorschrift na te leven en deze motieven interacteren op verschillende niveaus met elkaar. Persoonlijke motieven van managers of medewerkers kunnen worden geëxtrapoleerd naar de onderneming als geheel. Vice versa beïnvloeden organisatiedoelen en normen binnen de onderneming de motieven van individuele managers en medewerkers. Terwijl er vaak van wordt uitgegaan dat regelnaleving en -overtreding verklaard worden door economische motieven, hebben empirische studies de invloed van sociale en normatieve motieven op compliance en non-compliance laten zien. ${ }^{17}$

\section{Motivaties in het bank- wezen, de accountancy- en de trustsector}

Om factoren te achterhalen die van invloed zijn op het meldgedrag, worden hieronder de uitspraken van de respondenten in het bankwezen, de accountancy- en de trustsector geordend en gepresenteerd als economische,

14. R. Reno, R.B. Cialdini \& C.A. Kallgren, 'The trans-situational influence of social norms.' Journal of personality and social psychology, 64(1), 1993, p. 104

15. M. Gorsira, A. Denkers, L. Steg \& W. Huisman, 'Corruption in Organizations: Ethical Climate and Individual Motives', Administrative Sciences, 18, 2018, p. 1-19.

16. R. Paternoster \& S. Simpson, 'Sanction threats and appeals to morality: Testing a rational choice model of corporate crime', Law \& Society (30), 1996, p. 549.

17. M. Gorsira, A.J.M. Denkers \& W. Huisman, 'Both Sides of the Coin Motives for Corruption among Public Officials and Business Employees', Journal of Business Ethics, 2016, doi:10.1007/s10551-016-3219-2. 
sociale en normatieve motieven om de wettelijke plicht ongebruikelijke transacties te melden bij de FIU al dan niet na te leven.

\subsection{Economische motieven}

Zoals reeds besproken komt het economische motief voort uit een afweging die wordt gemaakt tussen de kosten en de baten die het melden van een ongebruikelijke transactie met zich meebrengt. Kosten worden niet alleen in geld uitgedrukt, maar vooral in de tijd en moeite om te melden. Naast het algemene belang van integriteit wordt alleen het voorkomen van de kosten van nietmelden genoemd: de kosten van handhaving.

Uit de interviews blijkt dat bij het maken van deze afweging een viertal elementen met name van belang zijn: het commerciële belang, het klantbelang, tijd en moeite en de afschrikkende werking van de handhaving.

Ten eerste speelt het commerciële belang een enorm grote rol in de keuze om al dan niet een melding te maken. Compliancemedewerkers raken meer dan regelmatig verwikkeld in discussies om collega's te overtuigen van het belang van de compliancevereisten en het melden van ongebruikelijke transacties. Zo stelt respondent 5 [Bank]: 'Er is altijd een heel groot conflict tussen ons belang, integriteit, het juridisch belang en het commercieel belang. Je hebt heel vaak de discussie met de relatiemanagers die zeggen: "Ja, maar hij zorgt wel voor $20 \%$ omzet hè" en dan zeg ik: "Daar heb ik geen boodschap aan", maar zij willen dan niet goed meewerken. En dan roepen mensen: "Jongens het commerciële belang mag nooit prevaleren boven het juridisch belang", maar dat is echt onzin, echt grote onzin want dat is niet hoe het op dit moment gaat.' Ook respondent 1 [Bank] geeft aan dat commercie vaak de boventoon voert: 'Bij compliance ligt gewoon nog steeds geen prioriteit want er wordt geen geld aan verdiend, het kost alleen maar geld.' Deze economische drijfveer sluit ook aan bij het de conclusie van het Openbaar Ministerie in het strafrechtelijke onderzoek naar de ING Bank waarbij werd gesteld dat 'business boven compliance ging. ${ }^{18}$ Het commerciële belang hangt ten tweede nauw samen met het klantbelang. Middels het werven en onderhouden van klanten wordt namelijk geld verdiend. Zo stelt respondent 19 [Trust]: 'Je hebt een onderneming dus je probeert uit commerciële hoek klanten binnen te halen en binnen te houden. Er wordt dan niet makkelijk afscheid genomen van een klant.' Aansluitend hierop spelen ten derde ook de tijd en moeite die gemoeid zijn met het doen van nader onderzoek en het maken van een melding een grote rol. Vooral het feit dat veel mensuren geïnvesteerd moeten worden om de compliancevereisten op orde te hebben, wordt gezien als een knelpunt voor het optimaliseren van de winstmarge. Zo stelt respondent 7 [Accountancy]: 'Je kan het ook niet declareren hè. Moet je voorstellen dat je tegen je klant zegt: "Ik krijg nog een rekening voor ingevulde witwassenmeldingen en discussies met compliance".' Men snapt de

18. Supra noot 3 wettelijke verplichtingen wel, maar het aanleidend onderzoek en het melden kost tijd, en dus geld. Zo stelt respondent 7 [Accountancy]: 'We snappen de verplichting, daar zal niemand over klagen, maar het is niet iets waar iedereen om staat te juichen en ook als je ertegen aanloopt dan is het gewoon vervelend. Dan moet je weer een complianceofficer bellen en dan krijg je een vragenlijst van d'r. Zij zijn nogal zwart-wit, dus je moet precies weten hoe het zit, dus daar ben je wel een tijdje mee bezig, het kost gewoon tijd.' Respondent 6 [Accountancy] sluit zich hierbij aan: 'Een melding bij de FIU kost me een halve dag.' Toch denkt niet iedereen hier hetzelfde over, zo stelt respondent 2 [Accountancy]: 'Met zo'n casus zijn ze dan toch al bezig. (...), maar als je het eenmaal ziet dan moet je er toch sowieso voor je jaarrekeningwerk wat aan doen. Je moet met die klant in gesprek sowieso van: "Hey, hoe kan dat nou wat is er aan de hand?" Nou als je dat eenmaal gedaan hebt dan is zo'n melding ook niet meer zoveel werk.'

Tot slot blijkt dat de handhaving van de Wwft-meldplicht volgens een deel van de respondenten een afschrikwekkende werking heeft en dus wordt gezien als 'kosten' in de afweging om al dan niet te melden. Zo blijkt dat de schikking van ING veel impact heeft gehad op de financiële sector en de aandacht voor regelnaleving. Zo stelt respondent 10 [Bank]: 'Zo'n ING-casus gaat iedereen hier aan het denken zetten: misschien moeten we toch nog wel wat onderzoek doen en nog meer melden.'

Ook respondent 6 [Accountancy] sluit zich hierbij aan: 'Het handhavingsrisico wordt heel hoog ingeschat. Dat je dus op je lazer krijgt als je het fout doet. En dat is wel een drijvende factor geworden.' En tevens respondent 16 [Accountancy] concludeert: 'Er zit zoveel extern toezicht op, de pakkans is best hoog.' De afschrikwekkende werking van de handhaving vormt dus een extrinsieke motivatie tot het melden van ongebruikelijke transacties. Dat geldt echter niet voor het deel van de respondenten dat juist stelt dat handhaving en boetes geen afschrikwekkende werking hebben. Zo stelt respondent 12 [Trust]: 'Nee die boetes werken niet, ja laat ik het zo zeggen, voor de kleine kantoren maakt het een heleboel uit want dat is geld uit je eigen portemonnee en dat je zelf de bak in kan draaien, maar voor die grote kantoren die werken bijna niet meer met persoonlijke directeuren, maar dat is allemaal een corporate director. Die kunnen ze niet de cel in gooien. Dan krijgen ze een boete, ja weet je, dat betalen ze gewoon. Dat maakt ze niet uit. Dat heb je bij ING ook gezien: oh we hebben witgewassen, hoeveel kost het? 700 miljoen, alsjeblieft, maar dan mag je ons niet vervolgen.'

Kortom, uit interviews blijkt dat dat respondenten een spanning tussen de compliancefunctie en de commerciële belangen ervaren, waarbij commercialiteit vaak prevaleert. Echter, het blijkt dat het handhavingsrisico hoog in wordt geschat sinds de historisch hoge boete van ING, waardoor een extrinsieke motivatie lijkt te zijn gecreëerd om te melden. 


\subsection{Sociale motieven}

Naast economische motieven spelen ook sociale motieven een rol in de keuze om ongebruikelijke transacties al dan niet te melden. Sociale motieven betreffen de perceptie van gedrag en verwachtingen van andere bedrijven en personen in de maatschappelijke omgeving omtrent de naleving van de meldplicht.

De interviews laten zien dat naleefgedrag tegelijk prescriptief normatief en descriptief non-normatief kan zijn. Zo weten respondenten dat het wettelijk verplicht is ongebruikelijke transacties te melden (prescriptief normatief), maar hebben zij de indruk dat niet veel collega's en concurrenten deze norm daadwerkelijk naleven (descriptief non-normatief). Deze discrepantie lijkt samen te hangen met de spanning tussen verwachtingen van 'de business', the first-line of defense, en compliance, the second-line of defense.

Prescriptieve normen van de eerste en de tweede lijn lopen volgens de respondenten sterk uiteen. Deze spanning zorgt voor een zekere mate van weerstand tegen het werk van compliance, wat niet bijdraagt aan het verkrijgen van de gegevens op basis waarvan moet worden beoordeeld of sprake is van een ongebruikelijke transactie. Die gegevens moeten namelijk vanuit de business komen. Zo stelt respondent 3 [Bank]: 'Vaak krijgen wij ook nog wel vragen waarom we het onderzoek doen. Heel veel bankiers weten helemaal niet wie we zijn. Ik heb wel eens gehad dat ik wel tot tien keer toe moest uitleggen wat ik aan het doen was en waarom ik dit deed. We hebben ook meetings gehad met bankiers, maar ja, je ziet toch dat ze het niet helemaal begrijpen. Ze willen gewoon geld verdienen en klanten helpen.' Ook respondent 4 [Bank] sluit zich hierbij aan en stelt: 'Binnen de first-line zie je wel wat vaak tegengas ontstaan. En daarmee bedoel ik echt de business, accountmanagers etc. Daar zie je wel wat tegengas. Ze willen het liever niet doen, maar ze onderkennen wel dat zij dat zouden moeten doen. Moeten doen, eigenlijk.'

De weerstand vanuit de business komt met name voort uit de relatie die relatiemanagers en accountmanagers hebben met hun klant. Wat de klant verwacht, is voor hen veel belangrijker dan wat de complianceafdeling verlangt. Met name bij de trustkantoren en de accountants staat de klantrelatie op gespannen voet met de meldingsbereidheid. Zo stelt respondent 11 [Trust]: 'Het melden van ongebruikelijke transacties is ook al niet fijn, daar is men ook al terughoudend in, omdat allereerst heb je een contract met een klant, dat is jouw klant.' De vertrouwde relatie met de klant kan een barrière vormen om een onafhankelijk oordeel te vellen over de ongebruikelijkheid van een transacties. Zo stelt respondent 16 [Accountancy]: 'Vertrouwdheid met de cliënt is een bedreiging van je onafhankelijkheid.' Daarnaast mag de klant niet worden ingelicht over een eventuele melding, terwijl dat toch niet altijd duidelijk blijkt te zijn volgens respondent 7 [Accountancy]: 'Ik krijg nog steeds de reactie: "Ik moet toch tegen mijn cliënt kunnen zeggen dat ik meld." En dan denk ik: nee! Dat is de hele essen- tie van die regelgeving dat je dat niet vertelt.' Kortom, de klantenrelatie zorgt ervoor dat er een zekere mate van zorgvuldigheid moet bestaan in de keuze om wel of niet te melden. Zo stelt respondent 2 [Accountancy]: 'Aan de ene kant kan je door de klant gepakt worden die zegt: "Je bent te onzorgvuldig in je afweging", of je wordt door BFT aangevallen omdat je niet tijdig hebt gemeld. Dus je moet wel keurig afwegen en dat ook vastleggen.'

Tot slot kan de potentiële reputatieschade die kan worden opgelopen door het niet naleven van de $\mathrm{Wwft}-$ verplichting een belangrijke motivatie zijn om wél een melding te maken. Imagoverlies heeft namelijk niet alleen een financiële grond, maar ook vooral een sociale basis. Organisaties willen hun goede reputatie behouden en werknemers willen trots zijn op het bedrijf waar zij werkzaam zijn. ${ }^{19}$ Zo stelt respondent 20 [Accountancy]: 'Waar mensen wel last van hebben op het moment dat je op een verjaardagsfeestje niet meer durft te vertellen dat je bij ING werkt. Of dat je regelmatig in de krant leest "door schandalen geplaagd". Daar word je gewoon niet vrolijk van.' Met het reputatiebelang lijken sociale en maatschappelijke normen vanuit de omgeving belangrijker voor naleving van de meldplicht dan het wettelijke vereiste. ${ }^{20}$ Zo stelt respondent 1 [Bank]: 'Ik denk dat reputatie de allerbelangrijkste reden is. Daar wordt ook veel op gehamerd bij trainingen dat het het belangrijkste is om de reputatie hoog te houden. Als jij klanten in de boeken hebt als terroristen of fraudeurs of witwassers en dat komt naar buiten, dan kom je er als bank superslecht vanaf.' Kortom, de reputatieschade die opgelopen kan worden door het opleggen van boetes en daarmee gepaard gaande publiciteit kan zorgen voor een versterking van de extrinsieke motivatie om te melden.

\subsection{Normatieve motieven}

Normatieve motieven worden in het kader van dit onderzoek gevormd door binnen de bedrijfscultuur gedeelde opvattingen en persoonlijke opvattingen over de meldplicht en het belang van de naleving ervan.

Een van meest aangehaalde opvattingen omtrent de meldplicht is de manier waarom deze moet worden nageleefd; volgens een rule-based benadering of volgens een risk-based benadering. Sinds de derde anti-witwasrichtlijn wordt een risk-based approach voorgeschreven waarbij de instelling zelf een inschatting moet maken van het risico dat de transactie een rol kan spelen bij witwassen. Echter, deze benadering zorgt voor verwarring aangezien de respondenten van mening zijn dat de toezichthouder nog steeds een rule-based approach eropna houdt. Zo stelt respondent 21 [Bank]: 'Maar als DNB dan binnenkomt en zegt: "Die transacties had je moeten melden", en jij zegt: "Nou ik vond eigenlijk om deze redenen van niet", dan zeggen ze: "Ja niet goed

19. K.C. van Wingerde, De afschrikking voorbij: Een empirische studie naar afschrikking, generale preventie en regelnaleving in de Nederlandse afvalbranche (Proefschrift). Erasmus Universiteit, Rotterdam, 2012.

20. J. van Erp, Naming en shaming in het markttoezicht. Een onderzoek naar de openbaarmaking van sancties op financiële markten. Den Haag: Boom Juridische Uitgevers, 2009. 
gedaan, punt." Dus dan krijg je weer de drang naar rulebased want dan hoef ik niet verder te kijken. Dat is voor mij ook een beetje het fundamentele probleem waar we nu in zitten.' Ondanks de risicogebaseerde aanpak die wordt voorgeschreven en de publiek-private samenwerkingen die gericht zijn op kwaliteit middels het prioriteren van thema's, krijgen de respondenten het idee dat het voornamelijk om de kwantiteit van meldingen gaat. Zo stelt respondent 8 [Bank]: 'De focus op volume vind ik fout, je zou het op kwaliteit moeten richten.' Ook respondent 9 [Bank] sluit zich hierbij aan: 'Ik zou willen dat als de opsporing zegt: "Wij hebben alleen maar focus voor drugs", moeten wij dan ook niet meer focussen op drugs? Zouden we daar niet met elkaar slimmer gebruik kunnen maken van de capaciteit die we in de keten hebben zitten. En dat wil echt niet zeggen dat we het capaciteitsdriven moeten doen, maar laten wij kijken wat we hebben zo slim mogelijk inzetten.' Volgens de respondenten bieden publiek-private samenwerkingsverbanden dan ook de uitkomst. Zo stelt respondent 8 [Bank]: 'Je zou eigenlijk naar echte samenwerking moeten gaan. Dus private-publieke samenwerking, dat je echt gewoon gezamenlijk zegt: "Dit zijn de prioriteiten van de komende jaren."”

Naast opvattingen over de aard van de regels heeft men ook een duidelijke mening over het belang van melden en de daarbij opgelegde poortwachtersfunctie. Zo geven alle respondenten aan dat het ze het belang van melden wel degelijk inzien. Zo stelt respondent 15 [Trust]: 'De meldplicht is niet ideaal, maar ik besef ook dat het eigenlijk nooit ideaal gemaakt kan worden. Je kan niet een wet schrijven op alle omstandigheden. Dus ja ongetwijfeld kan het beter, maar het feit dat er een meldplicht is, is noodzakelijk en dat moet ook.' Echter, de meldingsbereidheid wordt niet bevorderd door het meldprogramma 'Go-AML', dat niet gebruiksvriendelijk is. 'Echt om tranen van in je ogen te krijgen zo slecht', stelt respondent 6 [Accountancy]. 'Als je een melding doet dan verstuur je dat ding, in dat gruwelijke meldportaal, echt een vreselijk ding. Dan verstuur je 'm en vervolgens kan je dan je eigen melding niet printen en zo, je kan alleen je preview printen, maar dat is niet wat je gemeld hebt', vult respondent 17 [Accountancy] aan. Ook sluit het programma niet altijd aan op de transacties die gemeld worden. Zo stelt respondent 11 [Trust]: 'Dat meldportaal is gewoon een fucking drama. De transacties die trustkantoren verrichten laten zich daarnaast ook gewoon niet makkelijk in dat portal vangen.'

Naast het meldprogramma spelen ook de opvattingen omtrent het handhavend toezicht en de follow-up van FIU na het maken van een melding een rol in de meldingsbereidheid. De private actoren investeren namelijk enorm veel geld om hun poortwachtersfunctie zo goed mogelijk te kunnen uitvoeren, maar dit staat volgens de respondenten niet in verhouding met de capaciteit aan de publieke kant. Zo omschrijft respondent 17 [Accountancy]: 'Het zijn allemaal kosten voor het bedrijfsleven terwijl de overheid daar onevenredig aantal kosten tegenover heeft gesteld in het kader van opsporingscapaciteit.' Ook stelt respondent 21 [Bank]: 'Wat je ziet is dat banken hebben duizenden transacties gemeld bij de FIU, die hebben geen capaciteit om ze allemaal te behandelen. Ze hebben ook geen mensen. Ze hebben ook geen systemen. Ze zitten in dezelfde boot als de bank alleen ze kunnen geen boete krijgen.' Ook binnen de accountancysector hebben respondenten hetzelfde bezwaar: 'Ze hebben bij BFT 10 Fte op alle accountants, administratiekantoren, fiscalisten, advocaten, notarissen enz. van Nederland. Dat is dus samengevat de kans dat ze ooit komen toezicht houden is 0', stelt respondent 6 [Accountancy]. De citaten verwijzen naar het BFT en de FIU, maar deze opmerkingen zijn ook gemaakt over DNB waarbij verschillende respondenten al meer dan zeven jaar geen bezoek meer hebben gehad van DNB.

Het gebrek aan capaciteit vertaalt zich ook door in het uitblijven van follow-up van meldingen en feedback na het maken van een melding. Een veelgehoorde klacht onder de respondent is namelijk dat er geen terugkoppeling is over wat er met een melding gedaan wordt, terwijl dit juist een positief effect kan hebben op de meldingsbereidheid. Zo stelt respondent 6 [Accountancy] die cursussen omtrent de Wwft geeft: 'Dat vind ik zo demotiverend. Ik sta dan zo'n cursus te geven en te vertellen wat je allemaal zou moeten melden. En dan krijg ik de vraag: "Wat doen ze er dan mee?" En moet ik zeggen: "Ja niets." Dat is de werkelijkheid, ze doen er niets mee.' Een terugkoppeling van de melding zou volgens deze respondent ook helpen bij de keuze voor een volgende melding: 'Wat mij enorm zou helpen, is dat als we iets melden, dat er ook iets mee gebeurt. Dan wil ik op z'n minst een terugkoppeling van wat ze hebben gedaan en waarom ze het niet spannend vinden, want dan meld ik iets de volgende keer ook gewoon niet meer.' Ook respondent 21 [Bank] is het hiermee eens en stelt: 'Met die feedback kan je je monitoringssystemen verbeteren of je kan mensen opleiden. $\mathrm{Nu}$ gooi je het allemaal in een zwart gat: wat heb ik er nu aan dat ik meld?'

Tot slot sluiten de opmerkingen van respondenten in de accountancy aan bij de actuele discussie over de reikwijdte van de verantwoordelijkheid bij de controlerende werkzaamheden van de accountant. ${ }^{21}$ De respondenten zijn vrij eenduidig over de taakopvatting: 'Je mindset is niet: ik ga daar op zoek naar een ongebruikelijke transactie. Dat is niet onze taak', zegt respondent 16 . Ook respondent 17 zegt stellig: 'Het is alleen een poortwachtersfunctie, geen opsporingsfunctie dus je hoeft er niet naar op zoek.' En ook respondent 7 geeft aan dat hij er niet actief naar op zoek gaat: 'Bij toeval kan je er tegenaan lopen, nou oké dan moet je melden, maar het is absoluut geen kerntaak. De accountant kijkt of het goed is, niet of het fout is.'

21. Met als voorlopige stand het rapport van A.T. Ottow, E. Dijkgraaf en M.E. de Vries, Voorlopige bevindingen van de Commissie Toekomst Accountancysector, 2019. 
De bovengenoemde morele opvattingen omtrent de aard van de regels, de poortwachtersfunctie en de toezichthouders worden uiteraard ook beïnloed door de bedrijfscultuur en de tone at the top. Ook de respondent refereren hieraan. Zo stelt respondent 1 [Bank]: 'Ik heb het gevoel dat veel banken juist een hele goede complianceafdeling hebben en ook al zijn het jonge mensen dat ze echt goed weten waar ze mee bezig zijn, maar dat ze op veel vlakken worden tegengewerkt door management van hoger af waardoor hun werk een stuk moeilijker wordt gemaakt.' Ook respondent 21 [Bank] stelt dat de leidinggevende bovenin de organisatie uitmakt hoe compliant en integer een bedrijf is: 'Als een accountmanager zijn salestarget probeert te halen door een shitty klant naar binnen te fietsen of een shitty deal te sluiten dan ga ik niet naar hem toe, maar naar zijn baas. Want de accountmanager is een product van een cultuur wat van bovenaf wordt opgelegd. Dus als de baas zegt: "Nee natuurlijk niet", dan is het goed. Zegt die baas: "Ja dat weet ik allemaal wel, maar ja er moet ook geld verdiend worden dus hou even op met zeuren", dan ga ik wel weer naar zijn baas en zo door.' De tone at the top is dus volgens de respondenten cruciaal voor een breder draagvlak voor het belang van compliance.

\section{Conclusie}

In dit artikel is de vraag gesteld welke factoren een rol spelen bij meldingsplichtige instellingen om ongebruikelijke transacties te melden en hoe deze factoren motieven vormen voor het naleven van de de Wwft-meldplicht. Om deze vraag te beantwoorden is een kwalitatief onderzoek verricht waarbij vijfentwintig respondenten vanuit de bancaire, accountancy- en trustsector zijn geinterviewd.

Ten aanzien van de economische motieven blijkt dat de commerciële belangen in de eerste lijn van de organisatie op gespannen voet staan met het belang ongebruikelijke transactie te melden. Verder worden veel 'kosten' in termen van tijd en moeite gerapporteerd. De respondenten verklaren dat het extra onderzoek voor een melding soms te veel gevraagd is. Extra demotiverend zijn de uitgebreide meldprocedure en het gebruiksonvriendelijke meldprogramma Go-AML. Bij de accountancyen de trustsector komt daar nog het belang van het behouden van de klantenrelatie bij, waardoor men bij twijfel liever niet meldt.

Met betrekking tot de sociale motieven blijkt dat binnen de three lines of defense de prescriptieve normen uiteenlopen. Deze discrepantie zorgt voor spanning en weerstand vanuit de eerste lijn jegens de tweede lijn, de complianceofficers. Deze weerstand is met name toe te schrijven aan de klantrelaties die relatiemanagers hebben met hun klanten. Verder valt op dat respondenten niet verwijzen naar het al dan niet naleven van de meldplicht door andere bedrijven als sociale norm voor meldgedrag. Wel ervaren respondenten de algemene prescriptieve norm dat ten aanzien van hun onderneming de maatschappelijke verwachting bestaat dat ze de poortwachtersfunctie vervullen en de meldplicht naleven. In het bijzonder de potentiële reputatieschade die kan worden opgelopen, speelt een belangrijke rol in het naleven van de meldplicht. De respondenten geven aan dat voorkomen van reputatieschade een sterke motivatie vormt om te melden.

Wat betreft normatieve motieven onderschrijven de meeste respondenten het belang van het melden van ongebruikelijke transacties ter voorkoming van witwassen. Ze hebben echter kritiek op de manier waarop de meldplicht in de praktijk moet worden nageleefd. De respondenten onderschrijven de risk-based benadering die de wetgeving voorstaat, maar hekelen de rule-based benadering waartoe zij in hun beleving door de handhavingspraktijk worden gedwongen. Een bijkomende factor die van invloed is op de meldingsbereidheid is de gepercipieerde gebrekkigheid van de toezichthouders en de FIU bij de uitvoering van hun taken. De respondenten geven aan dat het gebrek aan terugkoppeling na een melding vanuit de FIU, het uitblijven van follow-up en daadwerkelijke veroordelingen op basis van meldingen en de onzichtbaarheid van de toezichthouder, het idee ondermijnt dat het melden van ongebruikelijke transacties effectief een bijdrage levert aan het bestrijden van witwassen. Hierdoor daalt de normatieve motivatie om een melding te maken.

Doordat het beperkte aantal respondenten geen representatieve steekproef is voor de drie sectoren, is generalisatie van de bevindingen niet mogelijk en is voorzichtigheid geboden bij het trekken van conclusies over motivaties voor het naleven van de $\mathrm{Wwft}$-meldplicht. Desalniettemin geven de resultaten aanwijzing dat het gebrek aan capaciteit aan zowel de private als publieke kant een negatief effect heeft op meldingsbereidheid. Volgens de respondenten is het dan ook belangrijk om meer focus te leggen op de kwaliteit van de meldingen dan slechts op de kwantiteit. Het is hierbij noodzaak om een echt risk-based beleid in plaats van een rule-based beleid te hanteren. Op deze manier zal de druk op de capaciteit afnemen en zullen de meldingen volgens de respondenten leiden tot een effectievere meldketen, waar meer veroordelingen uit voort kunnen komen. Daarvoor is aan private zijde meer kennis nodig over die risico's - waarvoor de banken informatie willen gaan delen - en dient risico minder in termen van reputatieschade te worden geoperationaliseerd. ${ }^{22}$ Aan publieke zijde is meer capaciteit en prioriteit nodig voor vervolg en terugkoppeling. De nabije toekomst zal leren in hoeverre de voorgenomen centrale transactiemonitoring in deze verbeterpunten voorziet. 